\title{
Performance of some high yielding garlic varieties at two locations of Bangladesh
}

\author{
M. U. S. Khatun*, M. Z. Ferdous, M. K. Islam and M. M. Anowar \\ On-Farm Research Division, Bangladesh Agricultural Research Institute, Alamnagar, Rangpur, Bangladesh \\ *E-mail: salma_agron@yahoo.com
}

\begin{abstract}
The experiment was conducted at Ulipur, Kurigram and Gabtoli, Bogra for two consecutive rabi seasons (2010-11 to 2011-12) to observe the performance of some high yielding garlic varieties ( BARI Roshun 1, BARI Roshun 2, BAU Roshun 1 and BAU Roshun 2) including local variety at farmer's field. In Kurigram, the highest yield (8.11 and 8.04 $\mathrm{t}$ ha $^{-1}$ during two successive years) was obtained from BARI Roshun 2, which differed significantly from other varieties. In Bogra, the highest yield (12.01 and $11.82 \mathrm{t} \mathrm{ha}^{-1}$ during two successive years) was obtained from BAU Roshun 2, which differed significantly from other varieties but in the second year it was statistically identical to BAU Roshun 1. In Kurigram, the highest gross return (Tk. 405500 and 241237 ha $^{-1}$ ) and the highest gross margin (Tk. 308325 and $97664 \mathrm{ha}^{-1}$ ) were obtained from BARI Roshun 2 where as in Bogra, the highest gross return (Tk. 960000 and $574000 \mathrm{ha}^{-1}$ ) and the highest gross margin (Tk. 826217 and $433081 \mathrm{ha}^{-1}$ ) were obtained from BAU Roshun 2 during two successive years. The lowest gross return and gross margin was obtained from local variety at both locations.
\end{abstract}

Keywords: Garlic, HYV, Yield, Cost, Return

\section{Introduction}

Garlic (Allium sativum L.) is one of the most important aromatic herbaceous annual spices under the family Alliaceae (Kurian, 1995). It is the second most widely used cultivated Allium after onion (Bose and Som, 1990) with a characteristic of pungent smell. Garlic was originated from central Asia, particularly Mediterranean region (Thompson and Kelly, 1957). Garlic has been recognized all over the world as a valuable spice for cooking different dishes. Garlic has been considered as rich source of carbohydrate, protein and phosphorus. It contains about $30-35 \%$ dry matter, $6-7 \%$ protein, $0.2 \%$ lipid and $23-28 \%$ carbohydrates. It also valued for its content of essential oil (Maly et al., 1998). Garlic plays an important role for the treatment of different types of disease such as chronic infection of stomach and intestine dysentery, typhoid, cholera and disease of lungs as Ayurvedi and Unani (Chopra et al., 1958). Aqueous extracts of garlic cloves (allicin and related disulphides) significantly reduce cholesterol level (Augusti, 1977). Garlic cloves extracts also play important role in reducing percent damping-off of tomato, eggplant and chilli seedlings (Islam and Faruq, 2012) and controlling anthracnose of mango, to increase the yield and quality mango per unit area (Chowdhury et al., 2007). In Bangladesh garlic cultivated in 37072 ha land and produces 164392 metric ton with an average yield of $4.43 \mathrm{t} \mathrm{ha}^{-1}$ (BBS 2010). The yield is quite low in the world context. This low yield may be due to the cultivation of the low yielding local varieties, incidence of diseases and insects, lack of technical knowledge etc. Spices Research Centre, BARI developed two garlic varieties namely BARI Roshon 1, BARI Roshon 2 and Bangladesh Agricultural University developed BAU Roshon 1, BAU Roshon 2 which are supposed to be high yielding varieties and less susceptible to insects, pests and diseases. These varieties have potential to help generate farmers' income in very short period of time. The present study was conducted to evaluate the performance of the varieties under farm condition and popularize them among the farmers to promote their adoption in the specific areas.

\section{Materials \& Methods}

The experiment was conducted to observe the performance of different modern garlic varieties at MLT Site, Ulipur, Kurigram, and MLT Site, Gabtoli, Bogra, for two consecutive rabi seasons (2010-11 to 201112). The land was medium high and the soil was sandy loam in texture. The experiment was laid out in a RCB design with six disperse replications having unit plot size $5 \mathrm{~m} \times 6 \mathrm{~m}$. There were five varieties viz. 
(BARI Roshun 1, BARI Roshun 2, BAU Roshun 1, BAU Roshun 2 and Local) at both the locations. In MLT site Kurigram, the Seeds (cloves) were sown during 7-12 November 2010 (Year 1) and 3-10 November 2011 (Year 2) with a spacing of $20 \mathrm{~cm} \times 10 \mathrm{~cm}$. Soil was fertilized with N-P-K-S-Zn-BCowdung at the rate of 115-54-165-20-4-1.7-5000 Kg ha-1 respectively. The entire amount of P-K-S-Zn-BCowdung and $1 / 2$ of $N$ were applied at final land preparation. Remaining $N$ was applied in equal two splits at 25 and 50 DAS as top dressing. The crop was harvested on 24 to 27 March in each year. In MLT site, Bogra the cloves were sown during 2-4 November 2010 (Year 1) and 29-30 October 2011 (Year 2). The crop was fertilized as per recommendation of Spices Research Centre (N-P-K-S-Cowdung at the rate of 100-53-167-20-5000 Kg ha ${ }^{-1}$ respectively), BARI. The entire amount of P-K-S- Cowdung and $1 / 2$ of $\mathrm{N}$ were applied at final land preparation. Remaining $N$ was applied in equal two splits at 25 and 50 DAS as top dressing. Irrigation was provided twice at 25 and 50 DAS. The crop was harvested on 24 to 25 March in each year. Plant protection measures and other intercultural operations were done as and when necessary at both the locations. Data on yield and yield contributing characters (weight of bulb with leaf plant $^{-1}$, weight of bulb without leaf plant- ${ }^{-}$, number of bulb $\mathrm{m}^{-2}$, no of cloves bulb ${ }^{-1}$, length of bulb and diameter of bulb) were taken and statistically analyzed following MSTAT software package.

Gross return (GR), total variable cost (TVC) and gross margin (GM) have been calculated using the following formula:

$\mathrm{GR}=$ Return of main product.

$=$ Yield Price (Tk.)

TVC = All input cost except land cost and interest on operating capital.

$\mathrm{GM}=\mathrm{GR}-\mathrm{TVC}$.

\section{Results and Discussion}

\section{In multi-location testing site, Kurigram}

The results presented in Table 1 revealed that there was significant difference among the varieties in respect of plant height $(\mathrm{cm})$, weight of bulb with leaf plant ${ }^{-1}$, weight of bulb without leaf plant ${ }^{-1}$ and number of bulb $\mathrm{m}^{-2}$ which might have increased yield significantly. The highest plant height was obtained from BARI Roshun 1 and the highest weight of bulb with leaf plant ${ }^{-1}$, weight of bulb without leaf plant ${ }^{1}$, number of bulb $\mathrm{m}^{-2}$ were recorded from BARI Roshun 2 which was significantly different from other varieties during two successive years. The highest yield (8.11and $8.04 \mathrm{t} \mathrm{ha}^{-1}$ during two successive years) was obtained from BARI Roshun 2 which was significantly different from other varieties. The lowest yield (6.38 and $5.50 \mathrm{t} \mathrm{ha}^{-1}$ during two successive years) was obtained from local variety.

Table 1. Yield and yield contributing characters of garlic at MLT site, Ulipur, Kurigram during 2010-11 to 2011-12

\begin{tabular}{|c|c|c|c|c|c|}
\hline Varieties & $\begin{array}{l}\text { Plant height } \\
(\mathrm{cm})\end{array}$ & $\begin{array}{c}\text { Wt. of bulb } \\
\text { with leaf plant }{ }^{-1}(\mathrm{~g})\end{array}$ & $\begin{array}{l}\text { Wt. of bulb without leaf } \\
\text { plant }^{-1}(\mathrm{~g})\end{array}$ & $\underset{2}{\text { Bulbs } \mathrm{m}^{-}}$ & $\begin{array}{l}\text { Yield } \\
\left(\mathrm{t} \mathrm{ha}^{-1}\right)\end{array}$ \\
\hline \multicolumn{6}{|c|}{ Year 1} \\
\hline BARI Roshun 1 & 69.84 & 35.50 & 18.83 & 49.16 & 7.86 \\
\hline BARI Roshun 2 & 67.02 & 37.02 & 19.47 & 49.27 & 8.11 \\
\hline BAU Roshun 1 & 68.00 & 35.23 & 19.10 & 48.93 & 7.94 \\
\hline BAU Roshun 2 & 64.20 & 36.63 & 18.25 & 48.83 & 7.87 \\
\hline Local & 65.00 & 33.38 & 18.00 & 47.67 & 6.38 \\
\hline $\mathrm{CV}(\%)$ & 6.01 & 5.75 & 3.77 & 0.88 & 5.45 \\
\hline LSD value $(0.05)$ & 5.198 & 2.614 & 0.909 & 0.557 & 0.685 \\
\hline \multicolumn{6}{|c|}{ Year 2} \\
\hline BARI Roshun 1 & 59.55 & 38.25 & 17.55 & 47.91 & 7.83 \\
\hline BARI Roshun 2 & 59.15 & 39.25 & 17.95 & 48.66 & 8.04 \\
\hline BAU Roshun 1 & 58.90 & 37.25 & 16.95 & 47.91 & 7.91 \\
\hline BAU Roshun 2 & 55.60 & 37.00 & 16.55 & 47.58 & 7.12 \\
\hline Local & 54.90 & 35.25 & 16.45 & 44.50 & 5.50 \\
\hline CV (\%) & 5.43 & 2.16 & 2.72 & 0.89 & 3.91 \\
\hline LSD value $(0.05)$ & 4.823 & 1.242 & 0.716 & 0.65 & 0.438 \\
\hline
\end{tabular}




\section{In multi-location testing site, Bogra}

The results presented in Table 2 revealed that there was significant difference among the varieties in respect of plant height $(\mathrm{cm})$, no of cloves bulb ${ }^{-1}$, length of bulb $(\mathrm{cm})$, diameter of bulb $(\mathrm{cm})$ and wt of bulb plant $^{-1}(\mathrm{~g})$ which might have increased yield significantly. The highest plant height $(60.60$ and $60.18 \mathrm{~cm}$ during two successive years) was obtained from BARI Roshon 1 . The highest number of cloves bulb ${ }^{-1}$ (27.65 and 27.47), length of bulb $(4.08$ and $4.23 \mathrm{~cm})$, diameter of bulb $(10.88$ and $11.04 \mathrm{~cm})$, and weight of bulb Plant $^{-1}$ (24.02 and $23.65 \mathrm{~g}$ ) were recorded from BAU Roshon 2 in the two successive years. The highest yield (12.01 and $11.82 \mathrm{t} \mathrm{ha}^{-1}$ during two successive years) was obtained from BAU Roshun 2 which was significantly different from other varieties but in the second year it was statistically identical to BAU Roshun 1. The lowest yield (6.23 and $6.00 \mathrm{t} \mathrm{ha}^{-1}$ during two successive years) was obtained from local variety.

Table 2. Yield and yield contributing characters of Garlic varieties at the MLT site, Gabtoli, Bogra during 2010-11 to 2011-12

\begin{tabular}{|c|c|c|c|c|c|c|}
\hline Varieties & $\begin{array}{l}\text { Plant height } \\
(\mathrm{cm})\end{array}$ & $\begin{array}{l}\text { No of } \\
\text { cloves } \\
\text { Bulb }^{-1}\end{array}$ & $\begin{array}{l}\text { Length of } \\
\text { bulb }(\mathrm{cm})\end{array}$ & $\begin{array}{l}\text { Diameter of } \\
\text { bulb }(\mathrm{cm})\end{array}$ & $\begin{array}{l}\text { Wt of bulb } \\
\text { Plant }^{-1}(g)\end{array}$ & $\begin{array}{c}\text { Yield ( } \mathrm{t} \\
\left.\mathrm{ha}^{-1}\right)\end{array}$ \\
\hline \multicolumn{7}{|c|}{ Year 1} \\
\hline BARI Roshun 1 & 60.60 & 20.78 & 3.75 & 9.73 & 13.20 & 6.60 \\
\hline BARI Roshun 2 & 58.1 & 23.20 & 3.85 & 9.90 & 16.78 & 8.40 \\
\hline BAU Roshun 1 & 60.55 & 24.43 & 3.93 & 9.68 & 21.33 & 10.67 \\
\hline BAU Roshun 2 & 59.47 & 27.65 & 4.08 & 10.88 & 24.02 & 12.01 \\
\hline Local & 53.43 & 19.00 & 3.30 & 9.36 & 12.47 & 6.23 \\
\hline LSD (0.05) & 5.159 & 1.473 & 0.403 & 0.6269 & 1.811 & 0.9037 \\
\hline CV (\%) & 7.33 & 5.31 & 8.59 & 5.25 & 8.56 & 8.54 \\
\hline \multicolumn{7}{|c|}{ Year 2} \\
\hline BARI Roshun 1 & 60.18 & 20.63 & 3.70 & 9.68 & 13.08 & 6.55 \\
\hline BARI Roshun 2 & 57.90 & 22.87 & 3.91 & 10.03 & 16.60 & 8.30 \\
\hline BAU Roshun 1 & 60.03 & 24.10 & 3.95 & 9.70 & 21.00 & 10.48 \\
\hline BAU Roshun 2 & 59.30 & 27.47 & 4.23 & 11.04 & 23.65 & 11.82 \\
\hline Local & 52.65 & 18.87 & 3.50 & 9.40 & 12.02 & 6.00 \\
\hline LSD (0.05) & 4.54 & 3.06 & 0.715 & 0.713 & 3.025 & 1.43 \\
\hline CV (\%) & 6.34 & 7.94 & 9.18 & 9.18 & 10.42 & 10.66 \\
\hline
\end{tabular}

\section{Cost and return}

Total variable cost (TVC) includes items of operation cost like, labour, ploughing, seed, fertilizer, irrigation and pesticides etc. In Ulipur, Kurigram labour cost was the highest (Tk. 21000 ha $^{-1}$ and Tk. 24000 ha $^{-1}$ ) during the two following years 2010-11 and 2011-12. The second highest cost was the fertilizer cost followed by seed, insecticides, irrigation and ploughing. The TVC of garlic in the year 2010-11 was Tk. $137175 \mathrm{ha}^{-1}$ and in the year 2011-12 was Tk. $143573 \mathrm{ha}^{-1}$. Similar results were found in Gabtali, Bogra in the two following years. The TVC of garlic in the year 2010-11 was Tk. $133783 \mathrm{ha}^{-1}$ and in the year 201112 was Tk. 140919 ha $^{-1}$ in Gabtoli, Bogra.

The economic performance of different garlic varieties are presented in Table 4 and 5 . In MLT site, Kurigram the highest gross return (Tk. 405500 and 241237 ha $^{-1}$ ), gross margin (Tk. 308325 and 97664 $\mathrm{ha}^{-1}$ ) and benefit cost ratio (2.96 and 1.68) was obtained from BARI Roshun 2 and in MLT site, Bogra the highest gross return (Tk. 960000 and 574000 ha $^{-1}$ ), gross margin (Tk. 826217 and 433081 ha $^{-1}$ ) and benefit cost ratio (7.18 and 4.07) was obtained from BAU Roshun 2 during two successive years. The lowest gross return, gross margin and benefit cost ratio was obtained from local variety at both the Locations. 
Table 3. Cost of production of garlic under different cost items in Ulipur, Kurigram and Gabtoli, Bogra

\begin{tabular}{|l|c|c|c|c|}
\hline \multirow{2}{*}{ Items of Operation } & \multicolumn{2}{|c|}{ Ulipur, Kurigram } & \multicolumn{2}{c|}{ Gabtoli, Bogra } \\
\cline { 2 - 4 } & $\mathbf{2 0 1 0 - 1 1}$ & $\mathbf{2 0 1 1 - 1 2}$ & $\mathbf{2 0 1 0 - 1 1}$ & $\mathbf{2 0 1 1 - 1 2}$ \\
\hline Labour & 70500 & 77700 & 61180 & 73500 \\
\hline Ploughing & 6000 & 6000 & 6000 & 6000 \\
\hline Seed & 21000 & 24000 & 28000 & 24000 \\
\hline Cowdung & 5000 & 5000 & 5200 & 5000 \\
\hline Urea & 3640 & 4400 & 2640 & 4400 \\
\hline TSP & 5720 & 6240 & 5720 & 6240 \\
\hline MoP & 8250 & 4950 & 8250 & 4950 \\
\hline Gypsum & 770 & 1110 & 770 & 1100 \\
\hline Boric & 1440 & 1440 & 1440 & 1440 \\
\hline Irrigation & 6000 & 4850 & 6000 & 5200 \\
\hline Insecticide & 8855 & 7883 & 8583 & 9089 \\
\hline Total & 137175 & 143573 & 133783 & 140919 \\
\hline
\end{tabular}

Table 4. Cost and return analysis of garlic varieties at MLT site, Ulipur, Kurigram during 2010-11 to 2011-12

\begin{tabular}{|c|c|c|c|c|}
\hline Varieties & $\begin{array}{c}\text { Gross return } \\
\left(\mathrm{Tk} \mathrm{ha}^{-1}\right)\end{array}$ & $\begin{array}{c}\text { Total variable cost } \\
\left(\text { Tk.ha }^{-1}\right)\end{array}$ & $\begin{array}{c}\text { Gross margin } \\
\left(\mathrm{Tk}_{\mathrm{h}} \mathrm{ha}^{-1}\right)\end{array}$ & BCR \\
\hline \multicolumn{5}{|c|}{ Year 1} \\
\hline BARI Roshon 1 & 393000 & 137175 & 255825 & 2.86 \\
\hline BARI Roshon 2 & 405500 & 137175 & 308325 & 2.96 \\
\hline BAU Roshon 1 & 397000 & 137175 & 259825 & 2.89 \\
\hline BAU Roshon 2 & 393500 & 137175 & 256325 & 2.87 \\
\hline Local & 369000 & 137175 & 231825 & 2.69 \\
\hline \multicolumn{5}{|c|}{ Price $\left(\right.$ Tk. $\left.\mathrm{kg}^{-1}\right)$ : Urea - 12, TSP - 22, MP - 25, Gypsum - 7, Boric acid - 180, Garlic - 50} \\
\hline \multicolumn{5}{|c|}{ Year 2} \\
\hline BARI Roshon 1 & 234997.5 & 143573 & 91424 & 1.63 \\
\hline BARI Roshon 2 & 241237.5 & 143573 & 97664 & 1.68 \\
\hline BAU Roshon 1 & 237487.5 & 143573 & 93914 & 1.65 \\
\hline BAU Roshon 2 & 213742.5 & 143573 & 70169 & 1.49 \\
\hline Local & 164992.5 & 143573 & 72819 & 1.15 \\
\hline
\end{tabular}

Price $\left(T_{k} \cdot \mathrm{kg}^{-1}\right.$ ): Urea - 20, TSP - 24, MP - 15, Gypsum - 10, Boric acid - 180, Garlic - 30

Table 5. Cost and return analysis of Garlic varieties at the MLT site, Gabtoli, Bogra During 201011 to 2011-12

\begin{tabular}{|c|c|c|c|c|}
\hline Varieties & $\begin{array}{c}\text { Gross return } \\
\left(\text { Tk.ha }^{-1}\right)\end{array}$ & $\begin{array}{c}\text { Cost of production } \\
\left(\mathrm{Tk}^{\left.-\mathrm{ha}^{-1}\right)}\right.\end{array}$ & $\begin{array}{c}\text { Gross margin } \\
\left(\mathrm{Tk} \cdot \mathrm{ha}^{-1}\right)\end{array}$ & $\mathrm{BCR}$ \\
\hline \multicolumn{5}{|c|}{ Year 1} \\
\hline BARI Roshun 1 & 528000 & 133783 & 394217 & 3.95 \\
\hline BARI Roshun 2 & 672000 & 133783 & 538217 & 5.02 \\
\hline BAU Roshun 1 & 853600 & 133783 & 719017 & 6.38 \\
\hline BAU Roshun 2 & 960000 & 133783 & 826217 & 7.18 \\
\hline Local & 498400 & 133783 & 364617 & 3.73 \\
\hline \multicolumn{5}{|c|}{ Market price of Garlic @ Tk $80 \mathrm{~kg}^{-1}$} \\
\hline \multicolumn{5}{|c|}{ 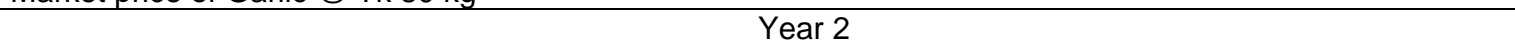 } \\
\hline BARI Roshun 1 & 327500 & 140919 & 186581 & 2.32 \\
\hline BARI Roshun 2 & 415000 & 140919 & 274081 & 2.94 \\
\hline BAU Roshun 1 & 524000 & 140919 & 383081 & 3.72 \\
\hline BAU Roshun 2 & 574000 & 140919 & 433081 & 4.07 \\
\hline Local & 300000 & 140919 & 159081 & 2.13 \\
\hline
\end{tabular}

Market price of Garlic @ Tk. $50 \mathrm{~kg}^{-1}$ 
Khatun et al.

\section{Conclusion}

From the two years study, it may be concluded that improved/HYV garlic varieties showed better performance than local variety and BARI Roshun 2 and BAU Roshun 2 gave higher yield in Ulipur, Kurigram and Gabtoli, Bogra respectively.

\section{References}

Augusti, K. T. 1977. Hypocholesterolaemic effect of garlic (Allium sativum L.). Indian J. Exp. Biol., 15(6): 489-790.

BBS. 2010. Statistical Pocket Book of Bangladesh. Bangladesh Bur. Stat., Stat. Div., Minist. Planning, Govt. People's Rep. Bangladesh.

Bose, T.K. and Som, G.M. 1990. Vegetable Crops in India. Naya Prokash, Calcutta, India, pp. 583-601.

Chopra, K.N., Chopra, I.C., Handa, K.L. and Kapur, L.D. 1958. Chopra's Indigenous Drugs of India. $2^{\text {nd }}$ Edn., UN Dhua Sons Private Ltd., Calcutta, pp. 271-274.

Chowdhury, M.N.A., Rahim, M.A., Khalequzzaman, K.M., Humauan, M.R. and Alam, M.M. 2007. Effect of Plant Extracts and Time of Application on Incidence of Anthracnose, Yield and Quality of Mango. Int. J. Sustain. Crop Prod. 2(5): 59-68.

FAO. 2004. Production Yearbook. Food and Agriculture Organization of the United Nations, 52: 59-60.

Kurian, J.C. 1995. Plant that Heal. Oriental Watchman Publishing House, Pune, India, p.31.

Mally I., Hlusek, J., Kopec, K., Petrikova, K., Rod, J. and Spitz, P. 1998. Polni zelinarstvi. Agro-spoj Praha, 5(2: 175-185).

Islam, M.T. and Faruq, A.N. 2012. Effect of Some Medicinal Plant Extracts on Damping-off Disease of Winter Vegetable. World Applied Sciences Journal 17 (11): 1498-1503.

Thompson, H.C. and Kelly, W.C. 1957. Vegetables crops. McGraw Hill Book Co., New York. pp. 368-370. 